\title{
openheart The introduction of refined carbohydrates in the Alaskan Inland Inuit diet may have led to an increase in dental caries, hypertension and atherosclerosis
}

\author{
James J DiNicolantonio, James H O'Keefe
}

To cite: DiNicolantonio JJ, 0 'Keefe $\mathrm{JH}$. The introduction of refined carbohydrates in the Alaskan Inland Inuit diet may have led to an increase in denta caries, hypertension and atherosclerosis. Open Heart 2018;5:e000776. doi:10.1136/ openhrt-2018-000776

Accepted 13 June 2018

Check for updates

Saint Lukes Mid America Heart Institute, Kansas City, Missouri, USA

Correspondence to Dr James J DiNicolantonio; jjdinicol@gmail.com
Recently, DiNicolantonio found evidence that an increase in the intake of refined carbohydrates and sugar may have lead to the increase in the incidence of atherosclerotic disease in the Greenland Inuit. ${ }^{1}$ Thus, we sought to determine if a similar event occurred in the Alaskan Inuit, and in particular, the Alaskan Inland Inuit.

The traditional Alaskan Inuit lived a semi-nomadic life hunting and catching fish, marine mammals and birds. However, beginning around 1920, a group of Alaskan Inuit slowly developed a permanent settlement in the mountains coming to live in Anaktuvuk Pass in $1950 .{ }^{1}$ In 1953, a post office was established as well as a 'white trader' store. Bang and Kristoffersen of the Gade Institute from the Department of Pathology and School of Dentistry in Norway performed two studies from two different time periods on the diet and dental health of the Alaskan Inland Inuit. They analysed the diet in 1955-1957 by "weighing of all the food eaten by each person for two consecutive days once a month during a 2-year period. At that time, samples of the food were analysed in order to determine the content of fat, protein and carbohydrate, as well as the total caloric intake of each individual'. ${ }^{1}$

In 1965 , the dietary intake was conducted by the 'interview method' plus personal observations when visiting all of the families during meal times. Bang and Kristoffersen '...contacted all of the Eskimos involved in the study questioning each individual in detail about what food and roughly how much of each food item he consumed in the course of the year'. ${ }^{1}$ The authors noted a dramatic increase in carbohydrate intake of 'nearly 50\%' and a decrease in the intake of protein 'by about 50\%' from 1955 to 1957 to $1965 .{ }^{1}$ This rise in the intake of carbohydrate was paralleled by an 'almost $90 \%$ increase' in the sum of decayed, missing and filled permanent teeth for primary teeth (from 3.0 to 5.6) and a fourfold increase in those $>6$ years old, 'the percentage of cariesfree persons had decreased from $74.5 \%$ to zero in 8 years... While $50 \%$ of the children in 1955-1957 had caries-free primary teeth all the children had decayed teeth in $1965 .$. The most dramatic change was observed in individuals 30 years of age or older. In this previously caries-free group, all subjects had developed caries in $1965{ }^{\prime}{ }^{1}$. Thus, the Alaskan Inland Inuit that had subsided on a diet virtually devoid of carbohydrate for most of their life who did not have any dental caries between 1955 and 1957 had all developed dental caries by 1965 ; in the interim, the intake of carbohydrate had increased by $50 \%$.

Bang and Kristoffersen elaborated on how the Alaskan Inland Inuit diet changed, 'While previously all able men in the village frequently were out hunting, trapping and fishing, only a couple of the young men were still actively engaged in such activities in 1965. Manufacture of souvenirs had proved more profitable and the income financed the purchase of refined foods from the local stores. Consequently, only some $20 \%$ of the food intake was made up of native foods, mainly caribou meat. Hunting was now mostly limited to the short periods when the caribou came close to the village. In 1955-1957, the percentage of calories obtained from protein and fat was high while the percentage derived from carbohydrate was low. In 1965, the intake of protein was about $50 \%$ lower 
(carbohydrate intake was 50\% higher)'. ${ }^{1}$ These details highlight the fact that these Eskimos were no longer subsisting on their native diet but instead a diet much higher in refined carbohydrates.

Importantly, the Anaktuvuk Pass Inuit of 1965 were 'living under the same environmental conditions as far as geographical location, climate, housing and clothing is concerned" compared with those from 1955 to 1957. Thus, the most dramatic environmental change in these Alaskan Inland Inuit during the 8-year study period was the change in their diet. The dental examinations in each time period were carried out by the same investigators using a similar method under identical conditions and it was said by these authors that an overestimation in the prevalence of dental caries in 1965 was highly unlikely as around half of the subjects were radiographed for dental caries in 1955-1957, whereas radiographs were not used in 1965. Thus, among the Alaskan Inland Inuit of Anaktuvuk Pass, an increased intake of refined carbohydrate of at least $50 \%$, and in some estimates as much as $200 \%$, was closely linked to a tremendous rise in dental caries. ${ }^{1}$

\begin{tabular}{|c|c|c|}
\hline & $\begin{array}{l}\text { Alaskan Inland Inuit } \\
\text { 1955-1957 } \\
\text { Studied by Bang and Kristoffersen }\end{array}$ & $\begin{array}{l}\text { Alaskan Inland Inuit } \\
\text { 1965 }^{1} \\
\text { Studied Bang and Kristoffersen }\end{array}$ \\
\hline Diet & $\begin{array}{l}\text { Fat: } 41 \% \\
\text { Protein: } 33 \% \\
\text { Carbohydrate: } 26 \%\left(\leq 13 \%{ }^{\star}\right) \\
\text { 'In } 1955-1957, \text { the percentage of calories obtained from protein and fat was high while } \\
\text { the percentage derived from carbohydrate was low'.' } \text { tImportantly, the } 26 \% \text { carbohydrate } \\
\text { estimate accounted for glycogen, which was not known at the time rapidly degrades to } \\
\text { lactate on death of the animal. Thus, the carbohydrate intake was likely }<13 \% \text {. } \\
\text { '...they previously lived a seminomadic life stopping at places where the hunting and } \\
\text { trapping proved best. In the summer they would migrate to the coast to fish and hunt } \\
\text { marine mammals and birds. Within the last two to three decades, however, they have stayed } \\
\text { permanently in the mountains'. }\end{array}$ & $\begin{array}{l}\text { Fat: } 40 \% \\
\text { Protein: } 15 \% \\
\text { Carbohydrate: } 45 \% \\
\text { 'The percentage of total calories obtained from protein had decreased by about } \\
50 \% \text { and that from carbohydrate increased by nearly } 50 \%{ }^{\prime} . \\
\text { 'While previously all able men in the village frequently were out hunting, trapping } \\
\text { and fishing, only a couple of the young men were still actively engaged in such } \\
\text { activities in } 1965 . . \text { the income financed the purchase of refined foods from the } \\
\text { local stores...only some } 20 \% \text { of the food intake was made up of native foods, } \\
\text { mainly caribou meat. Hunting was now mostly limited to the short periods when } \\
\text { the caribou came close to the village'.1 }\end{array}$ \\
\hline Dental health & $\begin{array}{l}\text { Prior to } 1960 \\
\text { 'few or no dental problems' in the “'Eskimos living on their native food'1 } \\
1955-1957 \\
\text { ' } 50 \% \text { of the children in } 1955-1957 \text { had caries-free primary teeth, all the children had } \\
\text { decayed teeth in } 1965 . . \text { The most dramatic change was observed in individuals } \geq 30 \text { years of } \\
\text { age. In this previously caries-free group, all subjects had developed caries in } 1965 \text { '. }\end{array}$ & $\begin{array}{l}1965 \\
\text { 'The change in diet was accompanied by a drastic increase in the prevalence of } \\
\text { dental caries'.' } \\
\text { The average number of affected teeth for primary teeth showed an 'Almost } 90 \% \\
\text { increase' in the sum of decayed, missing and filled permanent teeth } \\
\text { For those '....over } 6 \text { years of age exhibited a four-fold increase'.1 } \\
\text { 'The most dramatic change was observed in individuals } 30 \text { years of age or older. In } \\
\text { this previously caries-free group, all subjects had developed caries in the course } \\
\text { of } 8 \text { years'.1. }\end{array}$ \\
\hline
\end{tabular}

\begin{tabular}{|c|c|c|}
\hline & $\begin{array}{l}\text { Alaskan Inuit } \\
\text { (Alaskan Inland Inuit, published 1955) }^{2} \\
\text { Studied by Rodahl }\end{array}$ & Westernised populations \\
\hline Diet & 'Eskimos included in this study was about 2700 calories; the fat consumption was $105 \mathrm{~g} . . .2$ & Diet of USA in 1955 \\
\hline $\begin{array}{l}\text { Atherosclerosis } \\
\text { and } \\
\text { cardiovascular } \\
\text { disease }\end{array}$ & 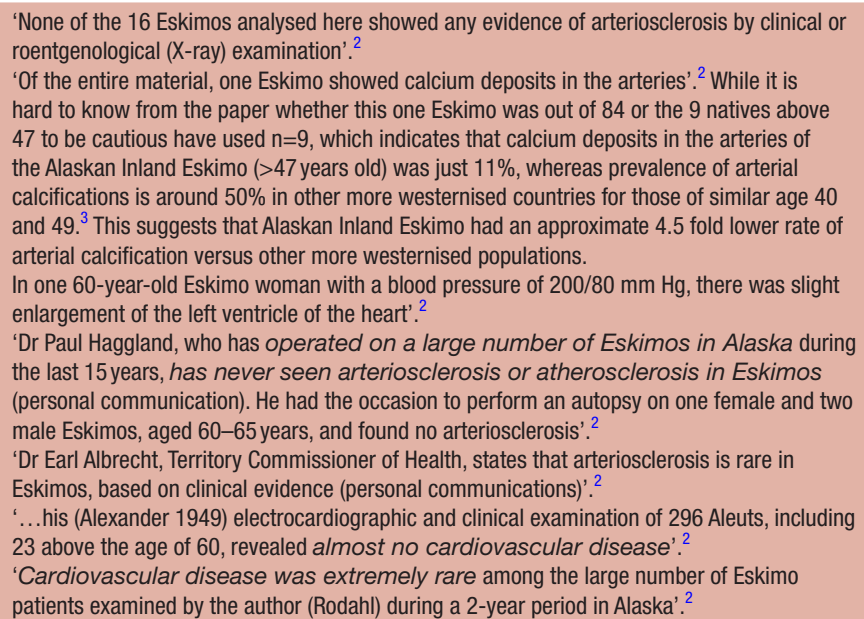 & $\begin{array}{l}71 \%-82 \%^{7} \\
\text { (cases with fibrous atherosclerotic plaques) } \\
58 \%-96 \% \\
\text { (cases with fibrous atherosclerotic plaques, all } 14 \text { countries studied). } \\
\text { Description: } \\
71 \%-82 \% \text { is from New Orleans (Blacks/Caucasians, respectively), in } 45-54 \text { years } \\
\text { old, } 1960-1965 \text {. } \\
\text { These data are from the International Atherosclerosis Project: } 1960-1965 \text { autopsy } \\
\text { study of } 23207 \text { sets of coronary arteries and aorta from } 14 \text { countries (table 10) in } \\
\text { men who died of accidents, cancer, infection and miscellaneous causes } \\
\text { 'Calcium is present in } 50 \% \text { of individuals aged } 40 \text { to } 49 \% \text { and } 80 \% \text { of individuals } \\
\text { aged } 60 \text { to } 69^{\text {'. }} \\
\text { A higher amount of calcification suggests more advanced atherosclerotic lesions in } \\
\text { other more westernised populations versus the Alaskan Inland Inuit } \\
77.3 \%^{8} \\
\text { (atherosclerotic coronary involvement). } \\
\text { Young Korean War vets, } 1953 \text { autopsy study. }\end{array}$ \\
\hline
\end{tabular}

†Eliminating glycogen, which would have been rapidly depleted from the animal on death would equate to a true carbohydrate intake of $\leq 13 \%$. 
'The Eskimo race is generally believed to have a low incidence of cardiovascular disease (Wilber and Levine, 1950), although their diet is apparently high in fat and cholesterol'.2

Apparently, a diet high in fat and cholesterol did not seem to have negative cardiovascular consequences for the Alaskan Inuit. Rodahl published a scientific paper in 1955 on the Alaskan Inland Eskimo indicating a daily caloric intake of 2700 calories, $37 \%$ of which was fat (105 $\mathrm{g}$ of fat per day). ${ }^{2}$ Another larger survey found that '... the average daily fat consumption in Alaskan Eskimos was $139 \mathrm{~g}$ (40\% of the calories) '. ${ }^{2}$ And the mean cholesterol intake was $340 \mathrm{mg}$ daily (varying from $150 \mathrm{up}$ to $700 \mathrm{mg}$ per day). ${ }^{2}$ These estimates were considered underestimates because the cholesterol content of certain foods was unknown at the time. Rodahl wrote, 'It may also be noted that the cholesterol intake varies greatly from one Eskimo group to another, depending on the different dietary habits. Thus it was observed that among the inland Eskimos, the Nunarniuts at Anaktuvuk Pass, some of the men consumed as much as $\geq 70 \mathrm{~g}$ of boiled brain from mountain sheep in a single evening meal yielding almost $600 \mathrm{mg}$ cholesterol from this food item alone'. ${ }^{2}$

Rodahl went on to write, 'In a survey of 104 Alaskan Eskimos the author found that both the systolic and diastolic blood pressures were lower in Eskimos than in Whites of corresponding age. Eighty per cent of the recorded systolic blood pressures were $<116 \mathrm{~mm} \mathrm{Hg}$ and no systolic blood pressure $>162 \mathrm{~mm} \mathrm{Hg}$ was ever recorded in our 'normal' Eskimo subjects. In a series of 117 Eskimo patients, only one of the patients had systolic blood pressure $>145 \mathrm{~mm} \mathrm{Hg}$ '. Thus, the rate of hypertension in Alaskan Inuit appears to be virtually non-existent $(1 / 117$ being around $0.85 \%)$ and about one-tenth the rate compared with that in the USA at the time.

Rodahl also noted that, 'None of the 16 Eskimos analysed here showed any evidence of arteriosclerosis by clinical or roentgenological (X-ray) examination, and cardiovascular disease was extremely rare among the large number of Eskimo patients examined by the author during a 2-year period in Alaska'.

Based on chest X-rays, Rodahl also noted, 'Of the entire material, one Eskimo showed calcium deposits in the arteries'. ${ }^{2}$ While it is hard to know based on the paper whether this was out of 84 Inuit or the 9 natives who were older than the age of 47 years, to err on the side of caution using the 9 natives, indicates that calcium deposits in the arteries of the Alaskan Inland Inuit $(>47$ years old) were at most $11 \%$. However, the prevalence of arterial calcifications in more westernised countries for those of similar age (40-49) is approximately $50 \%$. $^{3}$ This suggests that Alaskan Inuit had around one-fifth the prevalence of arterial calcifications. As calcium deposits in the arteries generally indicate more advanced atherosclerotic lesions, and since the Inuit apparently had a lower rate of calcifications, this may explain the lower rate of clinical cardiovascular disease based on autopsy. Indeed, it has been suggested that plaque rupture occurs at the interface between calcified and non-calcified sections of atherosclerotic plaque. ${ }^{3}$ Thus, it can be argued that a low rate of arterial calcifications in the Alaskan Inuit may have offered them protection from plaque rupture. Table 1 summarises the effects of a western diet on the health of the Alaskan Inland Inuit.

\section{CONCLUSION}

There was an approximate 50\% increase in the intake of refined carbohydrates in the Alaskan Inland Inuit from 1955 to 1957 to 1965 . This may have lead to the dramatic rise in dental caries and subsequent increase in atherosclerosis and coronary artery disease. ${ }^{14}$ The Alaskan Inuit eating a traditional low-carbohydrate, high-fat/protein diet had a much lower incidence of atherosclerosis, hypertension and dental caries versus more westernised populations. The health decline of the Alaskan Inland Inuit may have been driven by the rise in the intake of refined carbohydrates and sugar.

Contributors JJD: wrote the initial manuscript and performed the literature search. JHO'K: provided edits to the initial manuscript.

Funding The authors have not declared a specific grant for this research from any funding agency in the public, commercial or not-for-profit sectors.

Competing interests JJD is the author of The Salt Fix and operates the website thesaltfix.com.

Provenance and peer review Not commissioned; internally peer reviewed.

Open access This is an open access article distributed in accordance with the Creative Commons Attribution Non Commercial (CC BY-NC 4.0) license, which permits others to distribute, remix, adapt, build upon this work non-commercially, and license their derivative works on different terms, provided the original work is properly cited and the use is non-commercial. See: http://creativecommons.org/ licenses/by-nc/4.0/

(C) Article author(s) (or their employer(s) unless otherwise stated in the text of the article) 2018. All rights reserved. No commercial use is permitted unless otherwise expressly granted.

ORCID iD

James H 0'Keefe http://orcid.org/0000-0002-3376-5822

\section{REFERENCES}

1 Bang G, Kristoffersen T. Dental caries and diet in an Alaskan Eskimo population. Scand J Dent Res 1972;80:440-4.

2 Rodahl K. Diet and cardiovascular disease in the Eskimos. Trans Am Coll Cardiol 1955;4:192-7.

3 Wexler L, Brundage B, Crouse J, et al. Coronary artery calcification: pathophysiology, epidemiology, imaging methods, and clinical implications. A statement for health professionals from the American Heart Association. Writing Group. Circulation 1996;94:1175-92.

4 Fodor JG, Helis E, Yazdekhasti N, et al. "Fishing" for the origins of the "Eskimos and heart disease" story: facts or wishful thinking? Can J Cardiol 2014;30:864-8.

5 Dahl LK. Possible role of salt intake in the development of essential hypertension. 1960. Int J Epidemiol 2005;34:967-72. discussion 72-4, 75-8.

6 Johnson RJ, Segal MS, Sautin Y, et al. Potential role of sugar (fructose) in the epidemic of hypertension, obesity and the metabolic syndrome, diabetes, kidney disease, and cardiovascular disease. $\mathrm{Am}$ J Clin Nutr 2007;86:899-906.

7 Tejada C, Strong JP, Montenegro MR, et al. Distribution of coronary and aortic atherosclerosis by geographic location, race, and sex. Lab Invest 1968;18:509-26.

8 Joseph A, Ackerman D, Talley JD, et al. Manifestations of coronary atherosclerosis in young trauma victims--an autopsy study. J Am Coll Cardiol 1993;22:459-67. 
Correction: The introduction of refined carbohydrates in the Alaskan Inland Inuit diet may have led to an increase in dental caries, hypertension and atherosclerosis

DiNicolantonio JJ, O'Keefe JH. The introduction of refined carbohydrates in the Alaskan Inland Inuit diet may have led to an increase in dental caries, hypertension and atherosclerosis. Open Heart 2018;5:e000776. doi: 10.1136/openhrt-2018-000776.

In the end matter, 'Provenance and peer review' statement has been correctly updated as 'Not commissioned; internally peer reviewed'.

Open access This is an open access article distributed in accordance with the Creative Commons Attribution Non Commercial (CC BY-NC 4.0) license, which permits others to distribute, remix, adapt, build upon this work non-commercially, and license their derivative works on different terms, provided the original work is properly cited, appropriate credit is given, any changes made indicated, and the use is non-commercial. See: http://creativecommons.org/licenses/by-nc/4.0/.

C Author(s) (or their employer(s)) 2020. Re-use permitted under CC BY-NC. No commercial re-use. See rights and permissions. Published by BMJ.

Open Heart 2020;7:e000776corr1. doi:10.1136/openhrt-2018-000776corr1

(A) Check for updates 